\title{
Care without Control: The Humanitarian Industrial Complex and the Criminalisation of Solidarity.
}

\section{Geopolitics (2020)}

\section{Deanna Dadusc \& Pierpaolo Mudu}

https://www.tandfonline.com/doi/full/10.1080/14650045.2020.1749839\#.Xp2pQleOKC4

\section{Abstract}

In this paper we discuss the criminalisation of migrant solidarity, intended as practices of resistance to the current regulation and management of borders in Europe. We argue that the target of criminalisation is not simply humanitarian assistance: rather, we propose a differentiation between autonomous solidarity and humanitarianism, arguing that while the first is criminalised, the latter is often complicit in the harms and violence of borders. Drawing on critical humanitarian studies, we argue that autonomous migrant solidarity distinguishes itself from what we address as the 'Humanitarian Industrial Complex' in its active refusal to the legal obligations to control and report undocumented migrants to the authorities; its resistance to the racialised hierarchies entailed by humanitarian aid; as well as in its contestation of the commodification of migrant lives. Rather than 'filling the gaps' of the state or ameliorating borders and their violence, autonomous practices of migrant solidarity seek to 'create cracks' in the smooth operation of border regimes. It is because of their intrinsic character of opposition to both the militarisation of borders and to humanitarian technologies of government, we argue, that autonomous practices of 
migrant's solidarity are accused of 'facilitating illegal migration' and become the target of state repression.

\section{Introduction}

European border control and immigration policies are leading to the deprivation of migrants rights through detention and deportation to unsafe countries, increased violence at both internal and external borders, and the prevention of freedom of movement through deterrence policies and the closure of safe passages (Bigo 2014; Canning 2019; Heller and Pezzani 2018). While these constitute violations of human rights and of international law, and too often lead to death at the border, those responsible are rarely, if at all, addressed as criminally liable for this violence. Instead, paradoxically, those who attempt to resist border violence, by creating alternative practices, by acting in solidarity with migrants, often refusing to obey unjust laws, are often criminalised and repressed through a variety of legal and administrative techniques: from the 2002 'Facilitator package' at an international level (Council Directive 2002/90/EC of 28 November 2002), to Decrees at a national level, for example the Salvini's 2018 and 2019 Security decrees in Italy.

While this happens within the broader context of criminalisation of migration - the so called crimmigration (Stumpf 2006) - the criminalisation of migrant solidarity deserves a specific analytical framework. In November 2017 the Institute of Race Relations (IRR) published research on the criminalisation of humanitarianism, titled 'Humanitarianism: the unacceptable face of solidarity' (Fekete et al. 2017). Similarly, a recent report by IPOL (2018) analyses the 2002 'Facilitator package', and its role in the criminalisation of humanitarian assistance to border-crossers (Provera 2015). Both reports provide clear evidences of EU 
member states use of anti-trafficking and smuggling laws to extend criminalisation to those providing food, shelter and clean water to border crossers. Carrera et al. (2018) use the notion of 'policing the mobility society' to address practices that go beyond formal definitions of criminalisation (namely, arrests, prosecutions, convictions), and to include broader forms of intimidation and disciplining of activities in solidarity with migrants.

These discussions pay attention to the criminalisation of humanitarian practices and often call for a broader application of the 'humanitarian exception' to those practices that, rather than 'facilitating illegal immigration' through smuggling and trafficking, operate in a spirit of humanitarian solidarity with migrants. While providing in-depth analysis of these criminalisation processes, these analyses tend to blur the notions of humanitarianism and solidarity. In this paper we seek to complicate current debates and to question the concept of humanitarianism itself. In particular, we argue that the target of criminalisation is not simply humanitarianism: rather, drawing on critical humanitarian studies, we propose a differentiation between autonomous solidarity and humanitarianism, and we argue that while the first is criminalised, the latter is often complicit in the harms and violence of borders.

Specifically, the paper conceptualises autonomous solidarities as a resistance not only to the militarisation of borders and the criminalisation of migration, but also to the devices of government entailed with humanitarian borders. On the one hand, indeed, the externalisation and multiplication of borders has operated through securisation, militarisation and crimmigration. On the other, it has seen the deployment of a multitude of humanitarian forms of security: what Walters (2011) defines as 'humanitarian borders'. While seemingly opposed, these technologies of government are intertwined and mutually constitutive (Pallister-Wilkins 2018b). 
In this context, we propose the notion of 'autonomous solidarities' to address those practices that resist border regimes, as to differentiate them from broader notions of solidarity - which can range from states cooperation in migration management - and, in fact, human rights violations - to humanitarian solidarity. We argue that a differentiation between humanitarianism and autonomous forms of solidarity is necessary in order to understand current politics of criminalisation. Autonomous solidarity, we argue, operates as a form of political resistance, rather than humanitarian assistance (Dadusc 2019): resistance through the active refusal to the legal obligations to cooperate with the authorities and to report undocumented migrants; resistance to the racialised hierarchies created by humanitarian aid; resistance to the control and commodification of migrant lives. This leads us to an understanding of solidarity not as a practice that 'fills the gaps' of the state and other bordering agencies, but instead create cracks, resisting both the commodification and de-politicisation of border violence. Although acts of solidarity are not simply emancipatory, and are often tied into political hegemonic projects and territorial identities (Abji 2018; McNevin 2011), the autonomous solidarities discussed in this paper have represented one of the major challenge to the discourses and practices of bordering policies.

Therefore, the main aim of this article is to analyse the role of the criminalisation of autonomous forms of solidarity within the broader context of both humanitarian border management and criminalisation of migration. We argue that the criminalisation of autonomous forms of migrant solidarity goes hand in hand with the production of what we refer to as a 'Humanitarian Industrial Complex', which requires the repression of any practice outside of this framework.

While the purpose of this paper is to provide mostly an analytical intervention, it also draws on empirical materials that have been collected through formal interviews, workshops, 
media analysis and informal conversations with a multiplicity of actors affected by the criminalisation of migration, as well as with NGOs practitioners. This article, moreover, also draws on the authors' participation and engagement in border resistance in Italy, Greece and the Netherlands, as well as in transnational no-border networks.

\section{The 'immigration industrial complex'}

The EU and the European national governments are implementing measures, laws and practices to further criminalise migrants, framing them as a security threat and developing tactics of segregation and selective assistance: this becomes explicit in current forms of criminalization, detention and incarceration of migrants (Bosworth 2014; Martin 2012; Mountz 2011). The current convergence of migration and criminal law, that is crimmigration, is one of the key features of current migration policies (Stumpf 2006).

Bordering regimes to control migration and the use of the prison system have escalated at a level of a war. The war on migration has the following characteristics: 1) discourses of 'crisis' and 'emergency' related to an invasion that need to be stopped with any mean; 2) construction of migrants as public enemies; 3) suspension of human rights under 'organised crime' as well as 'anti-terrorism' legislations; 4) criminalisation of those who support the alleged public enemy. The war on migration in general terms makes use of structural violence deployed in physical, psychological, political and economic ways (Farmer 2004). In this war, we will argue, a crucial role is played by a disciplined humanitarian complex.

As already known from the history of migration in the USA, Canada and elsewhere (Hammar 1990; Goldring and Landolt 2013), there are "innovative" implications in the convergence of many national states and sovra-national bodies over the same model of interventions. In fact, the coordination of bordering practices and the governing of migration need to 
construct new subjects through selective citizenship and to transform existing political actors. This way, border controls consist of a constellation of actors which enact political strategies resembling a global apartheid (Van Houtum 2010) where the majority of migrants are refused entry into the Global North (Bialasiewicz 2012; Bigo 2014; Bowling and Sheptycki 2015).

The organization of human mobility has taken the form of a peculiar industrial activity (Andersson 2014), what Golash-Boza (2009) defined as 'the immigration industrial complex': namely, "the confluence of public and private sector interests in the criminalization of undocumented migration, immigration law enforcement, and the promotion of 'anti-illegal' rhetoric" (Golash-Boza 2009, 295). An industry is produced by intersecting economic interests of a multiplicity of actors that operate in the business of 'securing' borders: from private security forces, contractors and IT surveillance companies that provide the material infrastructures to build both militarised and digital borders (Amoore 2006; Pötzsch 2015). As Hyndman (2002) argued, borders breed profit and are more porous to the mobility of capitals than to human bodies, whose mobility is organised along racialised, colonial and economic hierarchies.

The concept of 'immigration industrial complex' draws from Angela Davis' (2003) 'prisonindustrial complex', introduced in her analysis of the links between capitalism, racism and the prison system. She defines the prison industrial complex as the convergence of actors and interests that profit from the prison industry, regardless of the actual need, or fabricating a need (Davis and Barsamian 1999). In particular, according to Davis, the actual function of the prison industrial complex is to provide a device of racial segregation, aimed not at solving problems but at depoliticising them and capitalising from them. The migration-industrial complex is to be comprehended as an essential element of the 
selection and organisation of the workforce with a social disciplinary role that is increasingly intersecting with the prison-industrial complex (Loyd et al. 2013).

\section{The Humanitarian Industrial Complex}

Current policies to select migration and control borders in Europe are vehiculated through the industry of repression, as well as through more subtle forms of control and discipline: namely, humanitarian assistance. Indeed, besides crimmigration and the militarisation of borders, a multiplicity of actors, moved by the invocation of tolerance as a moral practice, and seemingly operating against the reinforcement of 'Fortress Europe', are increasingly contributing to the constitution of what Walters has defined as "humanitarian borders" (Walters 2011). Moreover, increasingly, security practices are disguised and presented through humanitarian discourses (Aas and Gundhus 2015), with a multiplicity of state interventions, EU common security and defence policy missions and UN-led operations creating a new humanitarian-military nexus at the borders of Europe (Walters 2011; Tazzioli 2016). Often framed as bottom-up or 'radical' private and non-governmental initiatives work side by-side to institutionalised missions (Brown 2015; Ramsay 2019). In the face of the violent apparatus of borders militarisation, both governmental and non-governmental humanitarian interventions figure as the least of all possible evils (Weizman 2017). These, however, are designed to make borders violence tolerable and less visible, and constitute forms of governmentality that reproduce, strengthen and multiply the operation of borders control (Pallister-Wilkins 2018a).

Drawing on critical humanitarian studies (Barnett 2011; Chouliaraki 2012; Fassin 2011; Ticktin 2016; Walters 2011; Weizman 2017), we argue that rather than fostering autonomy and acting in solidarity with migrants' struggle, humanitarian operations often discipline, de- 
politicise and commodify the lives and subjectivities of those who allegedly receive their care. Therefore, an understanding of the Immigration Industrial Complex needs to take into account the stake of humanitarian practices and politics in fostering and profiting from this industry, as well as their role in the control and commodification of racialised bodies (Hayter 2001): what we address as the 'Humanitarian Industrial Complex'.

The Humanitarian Industrial Complex has a long colonial and imperial history (Barnett 2011), and constitutes the organisation of international and national institutions, NGOs, public and private assistance sectors activities in the selection and regulation of migrants, enforcement of laws (though contested), and the promotion of a charity rhetoric of tolerance as the only way to solve an alleged crisis or 'emergency' and 'help' migrants. Additionally, the Humanitarian Industrial Complex represents an important element to build devices toregulate and constrain the movements of people, and it is one of the main feature of current global bordering regime. While analysing the discursive and material practices of humanitarian politics, we will frame contentious and autonomous forms of solidarity not on a continuum with humanitarian assistance but instead as forms of resistance to the 'Humanitarian Industrial Complex', which operates though the commodification of suffering, subtle forms of care-control technologies, as well as subordination and discipline of migrants' agency.

Schematically, we can consider various features, with different narratives and purposes that are carried out by the immigration, humanitarian and prison complexes (Figure 1). The Humanitarian Industrial Complex contributes to criminalizing solidarity by accepting a logic of security and militarization, as well as by cooperating with a violent border regime, rather than contesting it. Moreover, the subordination of migrants' agency and the prevention of social solidarity, once they are framed within a war logic, that is at the intersection, 
interplay and integration between the Humanitarian Industrial Complex, the Prison Industrial Complex, and the Immigration Industrial Complex, become a fundamental purposes and features to sustain the war on migration and to reinforce racial segregation (Figure 1).

Figure 1: The Intersection among Immigration, Humanitarian and Industrial Complexes

\begin{tabular}{|c|c|c|c|c|}
\hline \multicolumn{3}{|c|}{ Immigration Industrial Complex } & \multicolumn{2}{|c|}{ umanitarian Industrial Complex } \\
\hline \multirow[t]{3}{*}{$\begin{array}{l}\text { - Regulate immigratio } \\
\text { - Confluence of public } \\
\text { device of racial segrega } \\
\text { problems but at depoli } \\
\text { > Constant repetition } \\
\text { uncontrollable flow, ar } \\
\text { rhetoric. }\end{array}$} & $\begin{array}{l}\text { dd private sector interests for a } \\
\text { on, aimed not at solving } \\
\text { ising them } \\
\text { 'terms such as: illegals, invasion, } \\
\text { the promotion of 'anti-illegal' }\end{array}$ & $\begin{array}{l}\text { - Institutionalizing neoliberal } \\
\text { policies } \\
\text { - Militarization of migration } \\
\text { pathways } \\
\text { - Complicity with political actors } \\
\text { who are responsible of the } \\
\text { "crisis" } \\
>\text { Construct ion of a figure of the } \\
\text { (un)deserving refugee }\end{array}$ & $\begin{array}{l}\text { - Aid during war, violent conflicts, } \\
\text { and migrants. Ensuring demilitarize } \\
\text { - Work of NGOs, often volunteers. } \\
\text { - Subordination to countries decisio } \\
\text { - }^{\text {"Neutrality" }} \text { "impartiality" and pa } \\
>\text { Spectacle of suffering and discour }\end{array}$ & $\begin{array}{l}\text { al emergencies, refugees } \\
\text { assistance. } \\
\text { nts victimization }\end{array}$ \\
\hline & $\begin{array}{l}\text { - Crimmigration: criminalization } \\
\text { of illegalized migrants, } \\
\text { immigration law enforcement, } \\
\text { production of social marginality } \\
\text { - Deportation } \\
\text { > Rhetoric of fear and emphasis } \\
\text { on terrorism }\end{array}$ & $\begin{array}{l}\text { - War on migration } \\
\text { - Subordination of migrants agency } \\
\text { - Prevent and stop social solidarity } \\
\text { - Criminalization of Solidarity } \\
\text { - Integration between public and } \\
\text { private actors to enforce } \\
\text { deportation and/or segregation } \\
\text { - Suspension of democratic rights } \\
\text { > Militarized diffused borders and } \\
\text { check points }\end{array}$ & $\begin{array}{l}\text { - Control of movement and } \\
\text { restriction of spaces } \\
\text { - Detention and biopolitical control } \\
\text { - Hotspots } \\
\text { > Binaries: "good" and "bad" }\end{array}$ & \\
\hline & \multicolumn{3}{|c|}{$\begin{array}{l}\text { - Regulate social norms and classes } \\
\text { - Convergence of actors and interests that profit from the prison industry, regardless of the actual need } \\
>\text { Punishment is used as the only way to address crime in particular of lower classes }\end{array}$} & $\begin{array}{l}\text { Purposes } \\
\text { Features } \\
\text { Narratives }\end{array}$ \\
\hline
\end{tabular}

Prison Industrial Complex

Source: Authors

In the first place we analyse the role of care-control humanitarianism in depoliticising and disciplining migrants' struggles; in the second place we discuss the role of humanitarian spectacles in allowing the commodification of migrants' lives. By exploring these processes, we discuss the role of humanitarian actors in becoming complicit in borders harms and violence. 


\subsection{Care, control and de-politicisation.}

Humanitarianism operates at the subtle border that divides those actions that seek to remedy for violence and casualties and those actions that lead to collaboration to the responsible of the violence. Extensive discussions and reflections have accompanied the development of humanitarianism in the past decades (Anderson 1999). The main paradox of humanitarian action is that it can contradict its fundamental purpose by prolonging the suffering it intends to alleviate and negative consequences can result from well-intentioned humanitarian action (Terry 2002). Historically, assistance and charity are portrayed as individual moral gestures detached from politics (Fassin 2011). In this line, institutionalised humanitarian organisations' and charities' mandates contain imperatives of a-political operations. Humanitarian work is framed as a work of care, as a missionary attempt to reduce suffering, not taking into account the politics of the conflict that produce these very sufferings. Yet, while presented as a practice that alleviates the violence and harms of borders, the Humanitarian Industrial Complex entails the operation of a device dedicated to de-politicising the conflict and enacting a selective gaze over borders violence.

The mandate of humanitarian missions and their obedience to Codes of Conduct, in terms of rules and ethical principles adopted for example during wars or Search and Rescue (SAR) operations, imposes principles of neutrality and impartiality (Cusumano 2018; Terry 2002). These codes were formulated to ensure that humanitarianism would be impartial in the context of conflict and war on a vague space 'outside' to the Global North. Yet, in the context of the violence of borders, these have increasingly operated on European territory, a new field for most of the organisations that have traditionally dealt with humanitarian emergencies in the 'Global South' (i.e Save the Children, the Red Cross, UNHCR and so on). 
While enforcing a logic of neutrality when acting within European territory, receiving EC funds, and seemingly protecting people from the harms perpetrated by the EU and its military forces (see 2016 EU-NATO agreement), many humanitarian organisations are supporting the interests, politics and policies of the EU itself, and suppressing any space for contestation of EU institutional violence.

The humanitarian assistance that we are addressing here has been defined as: "the provision of services that help migrants to access their fundamental rights (including to health care, shelter, hygiene and legal assistance) and to live with dignity" (Carrera et al. 2016: 47). The actors that compose what we critically defined as the Humanitarian Industrial Complex are workers, volunteers and activists who would often define their actions as in solidarity with migrants'.

There is often a fine line between spontaneous and informal actions when humanitarian work becomes institutionalized and commodified, institutionalizing neoliberal policies (Morris 2017). This is a strong paradox for humanitarian actors, particularly in war zones, and the new war against migrants has highlighted this characteristic. Participants of humanitarian organizations are in some cases aware of the issue, and for example the debate within Medicine Sans Frontiers addressed questions around responsibility for the role of humanitarian aid in the camps where they operate (Terry 2002). While these questions are paradoxes for some, they are acceptable forms of work for others. The purpose of this paper is not to evaluate individual's tendencies and faults, but instead to provide a critique to humanitarianism and to distinguish it from the practices of autonomous solidarity that are currently being heavily criminalised.

The construction of the current war on migration as a 'crisis' and 'emergency', used interchangeably by media, politicians and charities, serves as a discursive practice for the 
selection and organisation of migrants and conceptualization in terms of noun-formation of contemporary historical narrative on migration. The use of the word 'crisis' is highly problematic and it is a term to be contested (De Genova et al. 2015; Roitman 2014). The articulation of 'refugee crisis' evocates a situation 'outside of control' as well as 'outside of someone's responsibility. 'Crisis', indeed, is framed as an a-historical accident (PallisterWilkins 2018a), an abnormal rupture from the ordinary running of things, as a failure of a system. The frame of 'crisis' suspends the problem into a temporary departure from the norm (Marcuse and Madden 2016). Instead, what is currently defined as a 'refugee crisis' is the predictable and inevitable outcome of a racialised system of border violence and renewed imperialist gambling, that operate the very way it is intended. While erasing the historical and political process that lead to the situation, the language of crisis legitimises emergency responses (Ticktin 2016), mainly in terms of exceptional security measures and militarisation of borders, which eventually become rooted in everyday practices and normalised.

The alternative to militarisation as a response to the emergency of a crisis, is humanitarian benevolence: this often creates more harm than good, through a process that Miriam Ticktin (2016) defines as 'armed love' (Ticktin 2011), where compassion comes with repression, and the focus on individualised suffering overtakes the need for structural change. With the romanticisation of the suffering and innocent victim, as opposed to the stigmatisation of the threatening other, humanitarian sentiments of compassion and piety are mobilised. Indeed, this romanticisation narrows the focus to the suffering of individuals, diverting the attention away from the structural borders violence and erasing the histories and responsibilities of colonial and neo-colonial dominations (Cesaire 2001). By producing 'perfect innocent victims' vis-a-vis undeserving and guilty 'others', humanitarianism creates 
hierarchies of humanity between grievable and ungrievable lives (Butler 2006), reproducing gendered and racialised inequalities (Ticktin 2016).

The circulation of these representations and discourses, moreover, constitute the 'refugee' and the 'economic migrant' as specific subjects and distinct categories: either as a vulnerable victim or as a threat. The partition of populations into subpopulations is one strategy to make the global population governable. Discrete groups are governable through an updated "divide and rule" principle, through the creation, imposition, and perpetuation of a set of welcoming priorities among migrants of different nationalities, genders and ethnicities. In these divisions, or, to put it less resolutely, 'distinctions' of all sorts, is fundamental the work of the Humanitarian Industrial Complex in producing vulnerability as a privilege (Sözer 2019). Migrants need to prove their vulnerability in order to access aid and support. The biopolitical face of these relation, to rule over what forms of life are worth and which ones are not, is spectacularly unfolded. By placing the gaze on vulnerable bodies that need to be saved and rescued immediately, the language and spectacle of protection and assistance reinforces the operation of borders rather than challenging their institutionalised violence and searching for structural long-term solutions.

Moreover, recent studies on the humanitarian interventions in the context of the so-called refugee crisis, unmask the fine lines between care and control of the recipients of aid (Cuttitta 2017a; Cuttitta 2017b; Pallister-Wilkins 2018a). While borders fuel discontent, rage and potential resistance among displaced and immobilised populations, humanitarianism has the role of taming, channelling and subtlety repress this discontent. According to Agier (2011) forms of the de-humanisation enacted by humanitarian practices are intertwined with the erasure of the political subjectivity of those who receive aid. Hence, the power of humanitarian work is strongly entangled and aligned with border control authorities and 
European states: more often than not, humanitarian interventions produce paternalistic (patriarchal) hierarchies that are the result of long-lasting colonial power relationships and racist ideologies (Laidlaw 2012; Lester and Dussart 2014): protection comes with dependency and domination, and control to access to resources and services, e.g. in a refugee camp, serves as strong political tools to exercise authority over migrants and discipline their bodies. As much as the language of neutrality, the discourses of assistance and protection conceal the racial, historical and colonial powers and harms perpetrated by many European countries. Paternalism, encompassing both dominance and emancipation, has been indicated as the "positive organizing principle" of the international humanitarian order (Barnett 2012).

Refugee camps highlights coercive and disciplining techniques: "the use of particular reporting practices by UNHCR and other agencies are reminiscent of colonial practices that aim to standardize, control, and order the fields from which they were generated" (Hyndman 2000, xxviii). Hotspots are spaces of humanitarianism (Tazzioli 2016), where the integration between security and care lead to the constitution of semi-carceral spaces (Pallister-Wilkins 2018a). These spaces function because of the complicity of different actors in producing spaces of repression, that combine "interests of both states and humanitarian agencies for whom the concentration and segregation of refugees are politically and logistically expedient" (Newhouse 2015, 2294).

Ida Danewid's (2017) proposes a further critique of the ethics and politics of solidarity in the so-called "Black Mediterranean". Her arguments contends that these approaches, based on an ethics of compassion and piety, construct new political subjects around narratives of 'good whiteness' as opposed to the 'bad', nationalist whiteness (Saucier and Woods 2014), thereby failing to challenge the politics of white supremacy as such. Accordingly, this 
definition of European benevolence and innocence reproduces 'colonial amnesia and the erasure of connected histories' (Danewit 2017, 1681), resembling what Sarah Ahmed (2013) defined as 'stranger fetishism' and leading to a 'cannibalisation of the other masquerading as care'.

Therefore humanitarianism constitute rules, a moral conduct, a set of symbols and instructions to communicate and organize migration. This system of codes has a priority objective to provide the depoliticization of border violence and harms. These forms of depoliticization are twofold: on the one hand they entail "the rise of technocratic forms of governance" (Wood and Flinders 2014, 156). On the other hand, depoliticization is expressed in the "tendency of political actors to obscure the political character of politics and to present policy-making as a neutral, necessary and indisputable process, in which the possibility to choose between different political (not merely technical) alternatives, as well as that for disagreement and contestation, is limited or denied" (Cuttitta 2017a, 634). As a corollary, of the second form, both the criminalisation of migration and humanitarian assistance are offered as the only solutions to tackle the alleged 'migration problem'.

\subsection{Commodification of suffering}

There is also an economic dimension that goes beyond disciplinary relations of care and control that seems to be overlooked by existing literature on borders. Namely, the political economy of humanitarianism, the commodification of migrants suffering and of every aspect of their existence. Not only do humanitarian practices reproduce colonial and racialised hierarchies and structures, but their circuits of power are also configured through the transnational hyper-mobility of humanitarian financial capitals, as to contribute to the aforementioned Immigration Industrial Complex. Indeed, a new economy of aid has been created, transforming local economies of receiving countries. Many NGOs become suppliers 
detention centres, fuelling the industry of suppliers, local governments and other International Organisations (Scott-Smith 2019). This new economy has been rapidly developing and articulating with various forms of foreign aid and corporate humanitarian investments: both by importing expatriate professionals, their cultural practices and their modes of consumption, and by transforming the traditional forms of association and cooperation.

The spectacle of humanitarianism outlined above places people's bodies on display, enabling the mobilisation of large capitals flowing towards NGOs and humanitarian actors, often channelled or managed by private corporations, international foundations and the United Nations. Promotional materials of humanitarian organisations often portray voiceless children and women in desperate need of help and protection (Ticktin 2016). While these images deprive migrants of their agency, humanitarian organisations use them as marketing materials for raising donations, either in the form of money or goods (such as clothes, food, and medicines), thereby producing a top-down definition of migrants' needs. Ruben Anderson defines this form of commodification as 'predatory bio-economy', namely 'the extraction of value (...) from the very vitality - and, above all, misery - of human life itself' (Andersson 2014, 1). These new forms of value extractions are detached from traditional forms of labour, but turn migrants' bodies - their very presence and their conditions - into currencies.

As argued above, vulnerability becomes a commodity in the hands of the Humanitarian Industrial Complex, as well as a privilege in the hands of particular recipients, who are often put in a condition of competition with other 'less vulnerable' receivers (Krause 2014). From this perspective humanitarian interventions produce suffering and vulnerability, rather than their alleviation. Humanitarianism needs people's suffering to sustain its operation 
politically and economically. While some critiques of humanitarian assistance argue that this creates 'cultures of dependency', the opposite is true: it is humanitarianism that depends on people's suffering for its own existence and to keep itself indispensable. It is a double binding dependency relation.

While these forms of commodification lead to an explicit commodification of migrants' bodies, they also commodify and depoliticise possible responses. The act of giving by European donors becomes crystallized as the 'only possible solution'. The act of charity, the possibility of giving, rather than reflecting and acting, distracts donors from their structural privileges and their responsibility to formulate political solutions. A vicious circle is created, where the privileges in the EU are framed not as the source of the problem (borders violence for the protection of these privileges), but its solution. This way, these interventions inscribe themselves within existing power relations, with the effect of making these powers stronger, rather than weaker. Humanitarian interventions operate on the visible gaps of the border system in order to ensure its smooth operation, masking its fallacies while making them productive: not putting the system into a crisis, but rather benefitting from it and keeping its cracks under control. Therefore, humanitarianism and security play along similar lines and are mobilised for the same purposes (Pallister-Wilkins 2017).

In the remainder of this paper, we discuss to what extent the Humanitarian Industrial complex is contested and challenged by autonomous forms of migrants' solidarity solidarities, whilst supported and enabled by their repression. 


\section{Solidarity as Resistance to the Humanitarian Industrial Complex}

Recent literature exploring the political struggles of illegalised migrants places the focus on the contentious politics around the security and fortification of borders. According to the literature around 'acts of citizenship' (Nyers and Rygiel 2012), migrants have become political subjects not only in reaction to their precarious legal status, but also by organising themselves collectively to run their space of residence and work. The autonomy of migration approach, on the other hand, conceptualises border crossing itself as an act of resistance to the illegalisation of migrants lives and the securitisation of borders (Mezzadra 2010), by exceeding bordering practices (Squire, 2010) as well as producing what Papadopoulos, Stephenson and Tsianos (2008) have defined as 'mobile commons' ${ }^{1}$. The politicization of migrants and their autonomy from the regulatory systems of migration, open a space of dissent voices and material practices that unlock new spaces of action and new modes of life (Rancière 2004; 2010). Activism and political mobilisation by migrants, in particular by those illegalized, take multiple forms and implement a variety of tactics (Ataç et al. 2016; Miller 1981). Campaigns to request regularization of illegalized people (Laubenthal 2007) coexist with radical actions and solidarity beyond the frameworks of citizenship (Mudu and Chattopadhyay 2017; Dadusc et al. 2019).

In 2015, In Italy, Greece as much as in other European countries a multiplicity of solidarity responses preceded the Humanitarian Industrial Complex during what is commonly defined 'the long summer of migration' (Yurdakul et al. 2018): from self-organised settlements, 'Refugees Welcome' initiatives, autonomous rescue operations and squats to host and house people who arrived on the islands and in the cities. While solidarity toward illegalized migrants is often addressed as an 'act', as a temporary solution or as an individual gesture, 
the peculiarity of the current context is that, increasingly, networks of solidarity are emerging, creating new spatialities, temporalities and alliances (Dadusc et al. 2019). Spaces of convergence and solidarity between local solidarians, international supporters and migrants either in transit or inhabiting the spaces were created. In most European countries no border activism has produced various forms of political interventions against Europe, its states and its bordering regimes (Ataç et al. 2016; Mudu and Chattopadhyay 2017; Stierl 2018).

The peculiarity of contemporary migrant struggles and forms of solidarity that emerge in this context, is that they do not only oppose the politics of illegalisation, but also the micropolitics of humanitarian assistance (Dadusc 2019) - of which illegalisation is a conditio-sinequa-non - that operate directly on the bodies of migrants, within refugee camps and emergency centres, through the organisation of their food provision, circulation, their mental health as well as channelling their discourses and possibilities for action (Ramadan 2013; Dadusc et al. 2019). Instead of constituting separate fields of actions, these modes of solidarity are intertwined in the same struggle against the racialised domination and management of migrants' bodies and lives.

In addressing these practices as 'autonomous solidarities' we take distance from definitions of solidarity as a mere response to an injustice or oppression (Scholz 2008). Solidarity does not come as a mere reaction. Solidarity is not just opposition to existing forces, but it also prefigures new social patterns and social relations: the repression apparatus figures as a reaction and an enclosure of these ungovernable practices (Dadusc 2019; De Angelis 2019). Autonomous solidarities operates on different levels and take heterogeneous forms and temporalities: from isolated acts, to everyday relations that subvert the operation of borders, to collective autonomous practices and networks focussed on the creation of 
political and affective no-border spaces in border-zone, transit zones and arrival countries. Although the reality of these autonomous forms of migrants' solidarity presents several facets, contradictions and complexities, we contend that their political and ethical approaches distinguish themselves from the Humanitarian Industrial complex in several ways.

Solidarity has multiple meanings, no wonder that solidarity is not usually an isolated term and it is accompanied by an adjective: ethnic solidarity, feminist solidarity, group solidarity, social solidarity, national solidarity, intergenerational solidarity and so on. Featherstone (2012) defines solidarity firstly as 'a transformative relation'. Rather than being about likeness or similarity, he argues, it is about relations between places, activists and social groups. Secondly, he holds, it is 'forged from below', by marginalized and subaltern groups. Thirdly, it is marked by the 'refusal of political activity to stay neatly contained within the nation-state'. Fourthly, he argues that 'solidarities are constructed through uneven power relations and geographies' and, finally, that solidarity is 'inventive'; it constructs new political relations (Featherstone 2012). Our interest is on the reappearance of solidarity in the discursive political field. Solidarity is producing new political relations because it comes with respect and mutual learning, opposing charity and assistance, and people's possibility to take decisions on their own life and needs.

These practices refuse to become complicit in practices of border control, to capitalise from migration and to implement forms of care-control that subject migrants' lives and voices. Politically, autonomous forms of solidarity constitute practices that contest and challenge sovereign violence. The autonomous spaces spread throughout Europe, including squats, solidarity kitchens, info-points and 'welcome to Europe' networks, as well as practices of direct opposition to border violence (Dadusc et al. 2019; King 2016) bring forward material 
alternatives that pose themselves outside and against the violence of the state and of bordering regimes. Rather than relying on humanitarian ethics of control and 'compassion' for 'vulnerable others', these projects produce alliances with migrants struggles and carry on a common struggle against borders.

In doing so they produce critiques to discourses and practices that reject the language of 'crisis' as an exceptional state of current borders, and instead foreground the constitutive relations between migration, bordering, and the continuation of colonial violence, genocide and slavery. Rather than speaking a language of 'hospitality' and 'generosity' towards the 'suffering other' these practices and spaces seek to hold Europe, its states and its borders accountable and responsible for the historical and contemporary forms of violence (Heller et al. 2017; Pezzani and Heller 2013).

While assistance is organised in a hierarchical relation toward 'a receiver', people in solidarity try to organise themselves horizontally, 'hand in hand' or 'eye to eye' with someone (Cureton 2012). Here, solidarity is expressed through actions that do not seek to 'help', assist, contain, and immobilise migrants with top-down interventions. These practices subvert discourses of neutrality, assistance and protection. Instead, these challenge and refuse the control and commodification of migrants and the extraction of value from their mobility. Instead of reproducing the apparatus of assistance and detention and facilitating the management of migration, they aim at creating collective forces in resistance to detention, deportations and racialised hierarchies and violence (see Table 1). What has emerged is an autonomous, radical solidarity that has constituted new political subjectivities in overt antagonism to the formal humanitarian world (Dadusc et al. 2019). Solidarians actively attempt to avoid reproducing gendered, racialized, and class-based forms of inequality in their framing of humanitarian action. This risk has to be addressed by 
solidarians by refusing distinctions between "good" and "bad" migrant and by considering solidarity as a way to dismantle rather than "humanize" migration policies (Burridge 2009), thereby 'creating cracks' in the fortresses of Europe. Through these spaces and practices the visibility of migrants assume a strong critical assertion against the violence of a given situation and the possibilities of alternative ways to relate to migration and borders (De Angelis 2019; Rancière 2004; Swyngedouw 2011). The spaces where solidarity and a new politics of visibility are asserted, such as squatted self-managed places and sanctuaries, stand in opposition not only to the fortification of borders, but also to the operation of the Humanitarian Industrial Complex.

Their alleged dangerousness comes from their attempts to turning slogans as 'bridges not walls' and 'refugees welcome' into an everyday, permanent reality by seizing spaces of autonomy and freedom against and despite the politics of borders (Dadusc 2017).

\section{Table 1: solidarity versus assistance}

\begin{tabular}{|l|l|}
\hline Autonomous Solidarity & Humanitarian Assistance \\
\hline Resistance and prefigurative politics & Complicity with political actors who are \\
possibilities of social mixing and & Commodification of migrants bodies and \\
cohesion & suffering \\
\hline Common struggles making the & Depoliticisation of the violence of borders \\
violence of borders visible & \\
\hline Refusal to the legal obligations to & Cooperation with border police and \\
\hline
\end{tabular}




\begin{tabular}{|l|l|}
\hline report undocumented migrants to the & governments \\
\hline Provision of housing through squats & Temporary shelters in humanitarian camps \\
or solidarity networks & \\
\hline Ensure essential goods based on & Distribution of commodities as a charity act \\
\hline Re-elaboration of class politics based & Promotion of an interclassist homogeneity and \\
on a critical approach to the social & support to social inequalities \\
structure and its power relations & \\
\hline
\end{tabular}

Solidarity spaces and practices entail creating common grounds of struggles through horizontal, non-hierarchical and anti-authoritarian modes of organisation (Mudu and Chattopadhyay 2017). While these can be intended as practices of survival and adaptation, through solidarity new terrains of resistance are created, where the struggle is not just about ameliorating the conditions or obtaining citizenship, but the configuration of new social and political relations beyond and outside the spaces of citizenship. In these spaces, self-organisation, mutual aid and cooperation subvert the vertical racialised relations that enforce differentiations between givers and receivers. Here, migrants are valued as political subjects whose voices are not only listened but actively embraced. Rather than acting and speaking on behalf of migrants, the aim is to create alliances and coalitions with migrants, with an understanding that the fight against borders regimes is a common struggle of citizens and non-citizens (Dadusc 2017). 
Moreover, these forms of solidarity distinguish themselves from forms of humanitarian assistance in their active refusal to the legal obligations to report undocumented migrants to the authorities, solidarity enacts - in the context of militant knowledge production on migration - a 'selective disobedient gaze': namely, a gaze "that simultaneously refuses to disclose clandestine migration and reveal the violence of the border regime" (Pezzani and Heller 2013: 296). While taking distance from those forms of humanitarian interventions that cooperate with the authorities, spaces and practices of solidarity allow the multiplication of alliances to oppose and resist different bordering practices. Solidarity, as opposed to assistance, enables the disentanglement of the care and control principles, entailing radical politics of care without control.

Solidarity is expressed as a political practice rather than a humanitarian intervention, an act of resistance rather than an act of charity. Here the goal is not to provide plasters that make the situation more tolerable, nor to ameliorate the conditions of oppression, but to transform the very foundations of racialised border regimes, to counter the operation of the military-humanitarian borders nexus. Rather than relying on assistance and the fulfilment of pre-defined beyond basic needs, solidarity approaches entail struggles for seizing freedom of movement and of existence. This way no-border ethics and politics are enacted, creating spaces where migrants' lives are no disciplined and governed, and where border violence is not ameliorated but made visible and contested. Yet, solidarity is now recognized within illegal acts and sanctioned: these diverse modes of solidarity are seen as dangerous for the proposition of current migration policies, and those who do not cooperate with authorities are accused of facilitating illegal migration. 


\section{The criminalisation of autonomous solidarities}

Besides initial attempts to co-opt and institutionalise autonomous forms of migrant solidarity, strict measures enforced the criminalisation of any form of solidarity that would not fit under traditional humanitarian politics. In official discourses, these acts of solidarity are addressed as 'behaviour which assists irregular migrants either to enter or remain in the EU (which the Facilitation Directive describes as "facilitation"). The 2002 EU 'Facilitators' Package' sets the legal framework criminalising any form of facilitation of unauthorized entry, transit and residence. The Article 12 of the Facilitation Directive mentions the possibility of an exception to criminalisation when facilitation is carried on humanitarian grounds rather than for financial gain. However, these exceptional circumstances are not clearly defined, and the application of this exception remains at the discretion of the Member States. Moreover, 'humanitarian' is aleatory concept, leaving space for manipulation of the exemption by the authorities.

While these laws and regulations are used to criminalise and repress mostly migrants struggles for freedom of movement and are evidence of the most severe forms of criminalisation of migration (as in the case of Vos Thalassa in Italy, El Hiblu 1 in Malta, and migrant boats captains in the Aegean sea), our attention will be placed on their use for the criminalisation of solidarity with migrants. We are aware of the shortfall of this analysis, and of the risks of centring white subjects, and possibly 'white saviours' in the discussion around the criminalisation of migration, but the criminalisation of migrant struggles requires an in depth analyse that goes beyond the scope of this paper.

The new policy pattern implemented by the states is indeed bringing the criminalisation of migration to a further level, aimed at the construction of "solidarity crimes" (Carrera et al. 2018; Fekete 2018; Fekete et al. 2017). This new wave of criminalization has two major 
targets: on the one hand NGOs and other groups that support migrants and that through their practices are either explicitly or implicitly opposing border regimes, refusing to become complicit with the violence of borders. On the other hand, attack to individuals, spaces and networks can be tracked in recent legislation and police actions. Decrees have been promulgated in Italy and France forbidding citizens to give food and water to migrants; increasingly doctors, landlords and teachers are obliged to report irregular migrants to the authorities; squats and autonomous spaces face eviction and dispossession.

\subsection{Central Mediterranean: Search and Rescue NGOs}

The criminalisation of NGOs that provide independent infrastructure to create safe passages in the Mediterranean Sea, after the European Rescue operation MARE NOSTRUM was shut down, are the most evident target of the criminalisation of solidarity, and possibly in public discussions. In the Central Mediterranean, independent Search and Rescue organisations might cooperate with European authorities as to successfully conduct rescue operation. However, their criminalisation has often been the result of their refusal to obey unjust orders - including orders of disembarking those rescued to unsafe ports like Libya, or to sign codes of conducts that formalise their collaborations with authorities. Their presence at sea, rather than cooperating to border control and security, seeks to create safer passages as well as to monitor the operation of Frontex, denouncing European border politics as responsible of the thousands of death at sea (Heller and Pezzani 2018; Stierl 2018). The repression of these solidarity practices took many shapes: the use of criminal law, administrative sanctions, as well as the imposition of codes for disciplining, policing and institutionalising their operation (see Carrera et al. 2018).

An example is the investigation opened for acting against the 'code of conduct' that the Italian government imposed on SAR NGOs in the summer of 2017. In April 2017 the Italian 
Senate Defence Committee initiated an enquiry to investigate alleged cooperation between the independent SAR organisations and smugglers, and to determine the financing sources of independent SAR organisations. The Italian government obliged all independent SAR organisations to sign a "code of conduct", which required independent rescue organisations operating in the Mediterranean Sea to comply with rules and obligations. These included: "commitment to receive on board (...) judicial police officers for information and evidence gathering with a view to conducting investigations related to migrant smuggling and/or trafficking in human beings"; "commitment to loyal cooperation with the Public Security Authority of the migrants' intended place of disembarkation, including by transmitting relevant information of interest for investigation purposes to the Italian Police Authorities ${ }^{2 \prime \prime}$ (Avvenire 2017).

The Malta-based Migrant Offshore Aid Station (MOAS) and Spanish group Proactiva Open Arms agreed to the conditions, but Germany's Sea-Watch, Sea-Eye and Jugend Rettet, and France's SOS Mediterranée abstained. Among others, MAOS Sea Watch, MSF, and Jugend Rettet, rejected the 'code of conduct', taking issue with a clause in the code that would oblige groups to allow police officers on board to cooperate with the Italian police investigations, thereby becoming complicit in the criminalisation of migration. Although they later signed an amended version of the code of conduct, as a response to their refusal to accept state-led (and Frontex-led) norms, Italy seized rescue vessels, stranded them to the ports, banned them from national waters and arrested crew members under suspicion of 'assistance to illegal migration' in collaboration with Libyan smugglers (Cuttitta 2017b; Carrera et al. 2018; Medici Senza Frontiere 2017).

The accusations by Frontex, media and Parliamentarians against SAR NGOs was not only that independent SAR "collude with smugglers" for their own profit, but also that they 
intervene on Libyan waters, thereby constituting a "pull-factor" for migrants. In particular, Frontex published: "all parties involved in SAR operations in the Central Mediterranean unintentionally help criminals achieve their objectives at minimum cost, strengthen their business model by increasing the chances of success. Migrants and refugees - encouraged by the stories of those who had successfully made it in the past - attempt the dangerous crossing since they are aware of and rely on humanitarian assistance to reach the EU" (Frontex 2017: 32).

The case of the Sea-Watch 3 is for several aspects paradigmatic of the current spectrum of authoritarian direction in Italy and it came after a sequence of decisions and campaigns of the Italian government against SAR NGOs (Casiello and Venditti 2019; Porro 2019). In June 2019, the Italian interior minister Salvini has turned against the Sea-Watch 3 to demonstrate that the "ports are closed" and there can no longer be civil rescue fleets in the Mediterranean. As a consequence, after rescuing a migrant boat in urgent distress, the SeaWatch 3 was stranded in international waters for 17 days. The boat captain, Carola Rackete, defied the entry-ban to Italian territorial waters imposed by Salvini, and on June $29^{\text {th }}$ entered the port of Lampedusa to allow the disembarkation of the 42 migrants in a safe harbour. Carola Rackete was arrested on her arrival in Lampedusa, but soon after released by the judge of Agrigento, Alessandra Vella, because "saving the life of people at sea is a precise duty" (Tonacci and Ziniti 2019). Besides this and other exemplary cases of criminalisation, SAR NGOs activities are continuously hindered through administrative procedures, the confiscation of rescue vessels as well as the imposition of fines, which prevent their critical presence in the deadliest border of the world.

These criminalising discourses and strategies are remarkable for their capacity to flip the reality of the situation. While the European Union is signing agreements with Libyan militias, 
violating Human Rights conventions and turning the Mediterranean into the deadliest border of the world, it attempts to discredit, silence and imprison all those who disobey orders to return people to torture camps in Libya, who refuse to become complicit with the fortification of borders, and those who denounce the violence of European border regimes through their critical presence in the Mediterranean sea: a liquid cemetery that, under its waters, hides both thousands of deaths and the European responsibility for these deaths.

\subsection{Criminalisation of autonomous solidarity spaces and networks}

Besides SAR NGOs, a multiplicity of modes of solidarity and resistance are widespread on the Italian territory, where squats for migrants keep emerging and being evicted (Aureli and Mudu 2017; Mudu and Rossini 2018). Those squats self-managed by migrants have been the preferred target of the policies of repression of the last two years. Instances of "exemplary repression" episodes and violent evictions have been particularly significant in Rome, such as the eviction of the Salem Palace, or the building of via Curtatone, hosting migrants from North-East Africa. The policy of evictions has been openly transformed in a racist practice of selection of target populations and segregation measures that the Italian government, an alliance between Lega and Five Star movement, has proudly promoted. The latest "exemplary repression" has been inflicted to the mayor of Riace arrested for charges related to immigration in October 2018. In Italy and also internationally, Riace is considered a "model" of institutional support to migrants in one of the poorest area of Italy.

In Ventimiglia, an Italian city at the North-West border between Italy and France, activists who demonstrated in solidarity with migrants were forcibly transferred elsewhere in Italy, and volunteers providing support to migrants were detained and given a three-year ban from the town (Fekete et al. 2017). In February 2017, in France Cedric Herrou, was arrested 
for "facilitating irregular entry" for offering food and clothes to migrants in the Briançon region, an area where people undertake dangerous journeys to cross the Alps from Italy to France $^{3}$. On 10 January 2019 he was convicted to a three-month suspended prison sentence.

In Greece, in the aftermaths of the so-called 'refugee crises' while hundreds of humanitarian organisations and solidarity initiatives emerged on the hot-spots islands, all independent, unregistered activities were banned on January 28, 2016. All organisations, activities and individuals operating on the island were to be approved, registered, monitored, supervised and organised under state and police control. On February 21 2016, the Greek Parliament stipulated that the Greek Army would be responsible for the supervision of any service provided to stranded migrants, including housing, food, and medical assistance.

In Idomeni, on the Greek-North Macedonian border, an informal settlement was created by those stranded at the border, due to the closing of the Balkan Route. At the beginning of 2016 people from all over Europe organised independent forms of solidarity, providing facilities, food and legal support. Yet, they were accused of being 'fake volunteers', of steering and mobilising migrants protests, and of encouraging mass crossing of the border. Activist networks, solidarity kitchens as well as no-border squats were regularly harassed and evicted with the deployment of intimidation and violence. In January 2016, five independent volunteers acting in solidarity with migrants stranded on the Greek islands were arrested by the Hellenic Coast Guard (HCG) and faced charges of up to ten years of imprisonment for "felony of illegal transport from abroad to Greece of third country nationals, who do not have a right to enter the Greek territory" (Heller and Pezzani 2018)4. The objective of criminalization of these forms of migrant solidarity is to intervene in existing social relation, creating the condition for every citizen to become a border guard 
(Flynn, 2014), responsible for checking the immigration status not only of their tenants, employees, students and patients, but also of the people they meet on the street, exchange a meal with, host in their houses. These practices, on the one hand enforce a racist regime where each citizen is required to check and report the immigration status of people they encounter, on the other hand seeks to co-opt, discipline and repress any social relation between citizens and migrants that falls outside of the regimentalised fields of humanitarian assistance: what will be later defined as the Humanitarian Industrial Complex.

While those NGOs and other forms of humanitarian assistance that support and reinforce the management of migration are either tolerated or co-opted by the State, the examples of criminalisation discussed above target autonomous solidarity practices that do not accept to be inscribed within the pervasive framework of 'migration management'. Indeed, any activity from unregistered actors and forms of solidarity in non-official camps/squats became susceptible to charges of collusion with "criminal organisation" and "violation of the migration law". These forms of criminalisation aim at violently erase any autonomous and ungovernable form of solidarity and to facilitate the intervention of governable forms of humanitarian assistance.

What became clear from many episodes, is that humanitarian assistance is tolerated as long as it complies with strict rules and regulations imposed by European governments or border authorities. Those who refuse to become complicit, who act autonomously from these requirements, and who engage with alternative forms of solidarity are then criminalised and repressed. The alleged dangerousness of autonomous solidarities sheds light on the strict entanglements between humanitarian and securitarian border regimes. The current criminalisation of solidarity and the support to a highly disciplined Humanitarian Industrial Complex operates as an ordering principles that seeks to tame those autonomous practices 
that challenge and subvert the operation of borders. Moreover, the criminalisation of those who oppose and resist both humanitarian and securitarian borders has the objective of silencing all those voices that make borders violence and harms visible, thereby holding authorities accountable for their crimes.

\section{Conclusions}

In this paper we have addressed how the private sector and the humanitarian actors become integrated in the disciplinary and repression system, constituting a Humanitarian Industrial Complex. We have analysed the criminalisation of autonomous forms of solidarity towards migration as to understand how do these forms of criminalisation operate, and what role they play in the politics of bordering Europe. The criminalisation of autonomous solidarities, we argued, sheds light on the politics of humanitarianism, and unmasks the structural conditions under which traditional forms of humanitarian assistance operate. Therefore, target of criminalisation are those practices that challenge the codes of conduct of humanitarianism and that refuse to cooperate in violent and racist bordering policies.

As argued, spaces and acts of solidarity detach themselves from traditional humanitarian practices, and instead open a platform for political contestation of borders and migration policies. These constitute forms of resistance to the violence of borders by rejecting the forms of control, subjection and de-humanisation produced by humanitarian actors. In particular, we have discussed the different modalities in which solidarity distinguishes itself from the Humanitarian Industrial Complex: its active refusal to the legal obligations to cooperate with the authorities and to report undocumented migrants; its resistance to the racialised hierarchies created by humanitarian aid; as well as in its contestation of the commodification of migrant bodies. This way, autonomous migrant solidarity, as opposed to 
charity and assistance, does not aim at filling the gaps of the state but instead at creating cracks in the operation of the border. The criminalization of these is widening already existing crimmigration strategies and hindering any form of solidarity that organises against the care-and-control approaches of the 'Humanitarian Industrial Complex'.

\section{Acknowledgments}

We thank three anonymous reviewers for the many critics and suggestions that they have provided to us. We are grateful to the many constructive comments we received by the participants at the AAG conference in New Orleans in 2018 and at the SqeK meeting in Catania in 2018 where an earlier version of this paper was presented. We also thank the Solidarity Against Borders collective, as well as migrant communities and solidarity groups for the in-depth discussions and debates on the topic.

\section{References}

Aas, K. F., and H. Gundhus. 2015. Policing Humanitarian Borderlands: Frontex, Human Rights and the Precariousness of Life. British Journal of Criminology 55(1):1-18

Abji, S. 2018. Postnational acts of citizenship: how an anti-border politics is shaping feminist spaces of service provision in Toronto, Canada. International Feminist Journal of Politics 20(4):501-523.

Agier, M. 2011. Managing the Undesirables: Refugee Camps and Humanitarian Government. Cambridge: Polity.

Ahmed, S., 2013. Strange encounters: Embodied others in post-coloniality. London: Routledge.

Amoore, L. 2006. Biometric borders: Governing mobilities in the war on terror. Political geography 25(3):336-351.

Anderson, M. B. 1999. Do no harm: how aid can support peace-or war. Boulder: Lynne Rienner Publishers. 
Andersson, R. 2014. Illegality, Inc.: Clandestine migration and the business of bordering Europe. Oakland, CA: University of California Press.

Ataç, I., Rygiel, K. and M. Stierl. 2016. Introduction: The contentious politics of refugee and migrant protest and solidarity movements: Remaking citizenship from the margins. Citizenship Studies 20(5):527-544.

Aureli, A. and P. Mudu. 2017. Squatting movements: Reappropriating democracy from the state. Interface 9(1):497-521.

Avvenire. 2017. Code of Conduct for Ngos Undertaking Activities in Migrants' Rescue Operations at Sea.

https://www.avvenire.it/c/attualita/Documents/Codice\%200NG\%20migranti\%2028\%20lugli ०\%202017\%20EN.pdf.

Barnett, M. 2011. Empire of Humanity: A History of Humanitarianism. Ithaca: Cornell University Press.

Barnett, M. N. 2012. International paternalism and humanitarian governance. Global Constitutionalism 1(3): 485-521.

Bialasiewicz, L. 2012. Off-shoring and out-sourcing the borders of Europe: Libya and EU border work in the Mediterranean. Geopolitics 17(4): 843-866.

Bigo, D. 2014. The (in) securitization practices of the three universes of EU border control: Military/Navy-border guards/police-database analysts. Security Dialogue 45(3): 209-225. Bosworth, M. 2014. Inside immigration detention. Oxford: Oxford University Press. Bowling, B., and J. Sheptycki. 2015. Global policing and transnational rule with law. Transnational Legal Theory 6(1), 141-173.

Brown, W. 2015. Undoing the demos: Neoliberalism's stealth revolution. Cambridge, MA: MIT Press.

Butler, J. 2006. Precarious life: The powers of mourning and violence. London: Verso. Canning, V. 2019. Degradation by design: women and asylum in northern Europe. Race and Class (61):46-63.

Carrera, S., Allsopp, J. and L. Vosyliūtè. 2018. Policing the mobility society: the effects of EU anti-migrant smuggling policies on humanitarianism. International Journal of Migration and Border Studies 4(3):236-276.

Casiello, C., and Venditti M. E. 2019. Il caso Diciotti: tra obblighi di soccorso in mare e garanzia dei diritti fondamentali. [The Diciotti Affair: from the duty to rescue at sea to the protection of fundamental rights] DPCE Online, 39(2) (http://www.dpceonline.it/index.php/dpceonline/article/view/701). 
Césaire, A. 2001. Discourse on colonialism. New York: NYU Press.

Chouliaraki, L. 2012. Between Pity and Irony - Paradigms of Refugee Representation in Humanitarian Discourse. In Migrations and the Media, eds. K. Moore, B. Gross, and T. Threadgold, 13-31. New York: Peter Lang.

Corriere della Sera 2017. Sgombero a Roma, scontri tra migranti e agenti. 24 August 2017. Cureton, A. 2012. Solidarity and social moral rules. Ethical Theory and Moral Practice 15(5): 691-706.

Cusumano, E. 2018. The sea as humanitarian space: Non-governmental Search and Rescue dilemmas on the Central Mediterranean migratory route. Mediterranean Politics 23(3):387394.

Cuttitta, P. 2014. Borderizing the Island: Setting the Narratives of the Lampedusa Border Play. ACME: An International E-Journal for Critical Geographies 13/2:196-219;

Cuttitta, P. 2017a. Repoliticization Through Search and Rescue? Humanitarian NGOs and Migration Management in the Central Mediterranean. Geopolitics 23(3):1-29.

Cuttitta, P. 2017b. Delocalization, Humanitarianism and Human Rights: The Mediterranean Humanitarian Border between Exclusion and Inclusion. Antipode, 50(3):783-803 .

Dadusc, D. 2017. Squatting and the undocumented migrants struggle in the Netherlands. In Migration, Squatting and Radical Autonomy, eds. P. Mudu and S. Chattopadhyay, 275-284. Routledge, .

Dadusc, D., 2019. The micropolitics of border struggles: migrants' squats and inhabitance as alternatives to citizenship. Citizenship Studies, 23(6):1-15.

Dadusc, D., M. Grazioli, and M.A. Martínez. 2019. Introduction: citizenship as inhabitance? Migrant housing squats versus institutional accommodation. Citizenship Studies 23(6):521539.

Danewid, I., 2017. White innocence in the Black Mediterranean: hospitality and the erasure of history. Third World Quarterly 38(7):1674-1689.

De Angelis, M., 2019. Migrants' inhabiting through commoning and state enclosures. A postface. Citizenship Studies, 23(6):1-10.

Davis, A. Y. 2011. Are prisons obsolete?. New York: Seven Stories Press.

Davis, A. Y., and D. Barsamian. 1999. The prison industrial complex. Oakland, CA: AK Press.

De Genova, N., Mezzadra, S. and Pickles, J., 2015. New keywords: Migration and borders. Cultural studies 29(1):55-87.

Fassin, D. 2011. Humanitarian reason: a moral history of the present. Oakland, CA:

University of California Press. 
Featherstone, D. 2012. Solidarity: Hidden histories and geographies of internationalism. London: Zed Books Ltd.

Fekete, L. 2018. Migrants, borders and the criminalisation of solidarity in the EU. Race \& Class 59(4):65-83.

Fekete L., F. Webber, and Pettitt E.A. 2017. Humanitarianism: the unacceptable face of solidarity. London: Institute of Racial Relations.

Frontex. 2017. Risk Analysis for 2017. Warsaw: Frontex.

Golash-Boza, T. 2009. The Immigration Industrial Complex: Why We Enforce Immigration Policies Destined to Fail. Sociology Compass 3(2):295-309.

Goldring, L., and Landolt, P. (Eds.). 2013. Producing and negotiating non-citizenship:

Precarious legal status in Canada. Toronto: University of Toronto Press.

Hayter, T. 2001. Open borders: The case against immigration controls. Capital \& Class 25(3):149-156.

Hammar, T. 1990. Democracy and the Nation State: Aliens, Denizens and Citizens in a World of International Migration. Aldershot: Avebury.

Heller, C., Pezzani, L. and Stierl, M., 2017. Disobedient sensing and border struggles at the maritime frontier of Europe. Spheres: Journal for Digital Cultures, (4):1-15.

Heller, C., and L. Pezzani. 2018. Blaming the Rescuers. Criminalising Solidarity, Re-Enforcing Deterrence. Accessed February 11, 2020. https://blamingtherescuers.org/

Hyndman, J. 2000. Managing Displacement: Refugees and the Politics of Humanitarianism. Minneapolis: University of Minnesota Press.

Hyndman, J. 2002. BorderCrossings. Antipode 29(2): 149-176.

IPOL. 2018. Fit for purpose? The Facilitation Directive and the criminalisation of humanitarian assistance to irregular migrants: 2018 Update.

http://www.europarl.europa.eu/supporting-analyses

Italian Government. 2009. Pacchetto Sicurezza [Security Package]. Law 733-B.

King, N. 2016. No borders: The politics of immigration control and resistance. Zed Books Ltd. Krause, M. 2014. The Good Project: Humanitarian Relief Ngos And The Fragmentation Of Reason. Chicago: University of Chicago Press.

Laidlaw, Z. 2012. Slavery, Settlers and Indigenous Dispossession: Britain's empire through the lens of Liberia. Journal of Colonialism and Colonial History 13(1), doi:10.1353/cch.2012.0005..

Laubenthal, B. 2007. The emergence of pro-regularization movements in Western Europe. International Migration 45(3):101-133. 
Lester, A., and F. Dussart. 2014. Colonization and the origins of humanitarian governance: protecting Aborigines across the nineteenth-century British Empire. Cambridge: Cambridge University Press.

Loyd, J. M., M. Mitchelson, and A. Burridge eds. 2013. Beyond walls and cages: Prisons, borders, and global crisis. Athens: University of Georgia Press.

Marcuse, P., and D. Madden. 2016. In defense of housing: The politics of crisis. London: Verso Books.

Martin, L. 2012. 'Catch and remove': Detention, deterrence, and discipline in US noncitizen family detention practice. Geopolitics 17(2):312-334.

McNevin, A. 2011. Contesting citizenship: Irregular migrants and new frontiers of the political. New York: Columbia University Press.

Medici Senza Frontiere 2017. 5 motivi per non bloccare migranti e rifugiati in Libia. 11 September 2017 (http://www.medicisenzafrontiere.it/notizie/video/5-motivi-non-bloccaremigranti-e-rifugiati-libia)

Mezzadra, S. 2010. The gaze of autonomy: Capitalism, migration and social struggles. In The Contested Politics of Mobility, ed. V. Squire, 141-162. New York: Routledge.

Miller, M. J. 1981. Foreign workers in Western Europe: an emerging political force. New York: Praeger Publishers.

Morris, J. 2017. Power, capital, and immigration detention rights: making networked markets in global detention governance at UNHCR. Global Networks 17(3):400-422. Mountz, A. 2011. The enforcement archipelago: Detention, haunting, and asylum on islands. Political Geography 30(3):118-128.

Mudu, P., and S. Chattopadhyay. eds. 2017. Migration, Squatting and Radical Autonomy. New York: Routledge.

Mudu, P. and L. Rossini. 2018. Occupations for Housing and Social Centers in Rome: a Durable Resistance to Neoliberalism and Institutionalisation. In The Urban Politics of Squatters' Movements, ed. M.A. Martínez, 99-120. New York: Palgrave Macmillan. Newhouse, L. S. 2015. More than mere survival: violence, humanitarian governance, and practical material politics in a Kenyan refugee camp. Environment and Planning $A$ 47(11):2292-2307.

Nyers, P. and K. Rygiel. eds. 2012. Citizenship, migrant activism and the politics of movement. London: Routledge.

Pallister-Wilkins, P. 2017. Humanitarian Rescue/Sovereign Capture and the Policing of Possible Responses to Violent Borders. Global Policy 8, 19-24. 
Pallister-Wilkins, P. 2018a. Hotspots and the geographies of humanitarianism. Environment and Planing $D$.

Pallister-Wilkins, P. 2018b The Humanitarian Politics of European Border Policing: Frontex and Border Police in Evros. International Political Sociology 9(1):153-169.

Papadopoulos, D., N. Stephenson, and V. Tsianos. 2008. Escape Routes. Control and

Subversion in the 21st Century. London - Ann Arbor, MI: Pluto Press.

Pezzani, L., and C. Heller. 2013. A disobedient gaze: strategic interventions in the knowledge (s) of maritime borders. Postcolonial Studies 16(3):289-298.

Porro, A. 2019. Il dovere di soccorso in mare e la chiusura dei porti: I'esperienza della nave Aquarius. [The duty to rescue at sea and the closure of ports: the experience of the ship Aquarius] Minorigiustizia (1):151-157.

Pötzsch, H. 2015. Seeing and Thinking Borders. In Borderscaping: Imaginations and Practices of Border Making, eds. C. Brambilla, J. Laine, and G. Bocchi, 217-227 New York: Routledge. Provera, M. 2015. The Criminalisation of Irregular Migration in the European Union. CEPS Paper in Liberty and Security in Europe No. 80.

Raimondi, V. 2019. For 'common struggles of migrants and locals'. Migrant activism and squatting in Athens. Citizenship Studies 23(6):559-576.

Ramadan, A. 2013. Spatialising the refugee camp. Transactions of the Institute of British Geographers 38(1): 65-77.

Ramsay, G. 2019. Humanitarian exploits: Ordinary displacement and the political economy of the global refugee regime. Critique of Anthropology 39(4).

Rancière, J. 2004. 'Who Is the Subject of the Rights of Man?'. The South Atlantic Quarterly 103(2/3):298-310.

Rancière, J. 2010. Dissensus: On Politics and Aesthetics. London: Continuum.

Roitman, J. 2014. Anti-crisis. Durham: Duke University Press.

Saucier, P.K. and T.P. Woods. 2014. Ex aqua: The Mediterranean basin, Africans on the move, and the politics of policing. Theoria 61(141):55-75.

Scholz, S. J. 2008. Political solidarity. University Park: Pennsylvania State Press.

Scott-Smith, T.O.M. 2019. Beyond the boxes: Refugee shelter and the humanitarian politics of life. American Ethnologist 46(4):509-521.

Sözer, H. 2019. Humanitarianism with a neo-liberal face: vulnerability intervention as vulnerability redistribution. Journal of Ethnic and Migration Studies, doi:10.1080/1369183X.2019.1573661. 
Squire, V. 2010. The contested politics of mobility: politicizing mobility, mobilizing politics. In The Contested Politics of Mobility ed. V. Squire, 21-46. New York: Routledge.

Stierl, M., 2015. The WatchTheMed Alarm Phone. A Disobedient Border-Intervention. movements. Journal for Critical Migration and Border Regime Studies, 19(5): 561-578.

Stierl, M., 2018. A fleet of Mediterranean border humanitarians. Antipode 50(3):704-724.

Stumpf, J. 2006. The Crimmigration Crisis: Immigrants, Crime, and Sovereign Power.

American University Law Review 56(2):367-419.

Swyngedouw, E . 2011. Interrogating post-democracy: reclaiming egalitarian political spaces. Political Geography 30 (7):370-380.

Tazzioli, M. 2016. Border displacements. Challenging the politics of rescue between Mare Nostrum and Triton. Migration Studies 4(1):1-19.

Terry, F. 2002. The paradox of humanitarian action: Condemned to repeat. London: Cornell University Press.

Ticktin, M. 2011. The gendered human of humanitarianism: medicalising and politicising sexual violence. Gender \& History 23(2):250-265.

Ticktin, M. 2016. Thinking Beyond Humanitarian Borders. Social Research 83(2):255-271.

Tonacci, F., and A. Ziniti. 2019. Sea-Watch, Carola Rackete è libera: "Commossa". Gip annulla l'arresto: "Agì per portare in salvo i migranti". L'ira di Salvini. La Repubblica, 2 July 2019. Van Houtum, H. 2010. Human blacklisting: the global apartheid of the EU's external border regime. Environment and Planning D: Society and Space 28(6):957-976.

Walters, W. 2011. Foucault and Frontiers: Notes on the Birth of the Humanitarian Border. In Governmentality: Current Issues and Future Challenges, eds. U. Bröckling, S. Krasmann, and T. Lemke, 138-164. New York: Routledge.

Weizman, E. 2017. Least of all possible evils. London: Verso Books.

Wood, M., and M. Flinders. 2014. Rethinking Depoliticisation: Beyond the Governmental. Policy \& Politics 42(2):151-170.

Yurdakul, G., B. Zur Nieden, E. Fontanari, K. Wolf, O. Keskinkılıç,A. Ménétrier, and S. Bellezza. 2018. Witnessing the transition: Moments in the long summer of migration. Berlin: Humboldt-Universität zu Berlin.

\footnotetext{
${ }^{1}$ Mobile common is the knowledge and affective reservoir produced by innumerable and uncoordinated but cooperative actions of people, that offer vital resources and energies to the migrants on the road or when they arrive in a new place (Papadopoulos and Tsianos, 2012).
} 
${ }^{3}$ After the first conviction, the French Constitutional Court had declared the legislation incompatible with the French constitutional principle of fraternité. Nevertheless, Cedric Herrou's was eventually found guilty and convicted. 